\title{
Tropical Urbanisation and the Life of Public Housing in Singapore
}

\author{
Adrian T. H. Kuah \\ James Cook University Singapore
}

\begin{abstract}
The rapid pace of urbanisation in the tropics is astounding. By 2050, 2.5 billion people will be added to the world's urban population, with nearly $90 \%$ of this increase taking place in tropical Asia and Africa. Cities such as Mumbai, Kolkata, Manila, Lagos, Guangzhou, Shenzhen, Jakarta and Singapore have witnessed sharp increases in their populations. Housing this population is a critical concern of contemporary cities of the tropics. This paper highlights the case of Singapore, which has managed to provide housing to almost every person in the country through its public housing policy. Singapore's public residential concept illustrates a successful approach to executing an urban development concept plan that optimises the use of limited land in a small country. Although such an achievement may not be easily replicated, this paper highlights three lessons that may be applicable to tropical urbanisation: implementing a sustainable housing development and urban planning policy; creating social cohesion through a public housing program; and potentially, enhancing social mobility through home ownership.
\end{abstract}

Keywords: urbanisation, urban planning, public housing, Singapore

\section{Tropical Urbanisation}

7 he tropics $\left(15^{\circ} \mathrm{N}\right.$ to $\left.15^{\circ} \mathrm{S}\right)$ are home to $40 \%$ of the world's population, or more than 2.8 billion people. The latter figure represents an increase of more than 2 billion people since 1950 and equates to a growth rate of $2.2 \%$ per annum, considerably higher than the growth of $1.4 \%$ per annum in the rest of the world. ${ }^{1}$

\footnotetext{
${ }^{1}$ For an overview of the importance and growth of the tropic see Harding et al. 2016.
} 
Infrastructure needs are especially acute in the region (Harding et al., 2017). With economies growing $20 \%$ faster than the rest of the world, with high rates of urbanisation, and with growing consumption but a disproportionate share of poverty and inequality, the tropical region is on the verge of an infrastructure boom. Asia's urban population growth is unprecedented and will double in size to reach 3.2 billion by 2050 (Marcotullio, 2001; Sandhu \& Singru, 2014). This growth is equivalent to an additional 100,000 urban residents each day. By 2050 , more than half the world's population will live in the tropics (every two out of three children will live there).

Almost 99\% of the tropical population lives in nations considered 'developing'. According to the World Bank (2015), 21\% of the tropical population currently resides in low-income nations, another $54 \%$ in lower-middle-income nations, and the remainder in upper-middle-income and high-income nations. Of the 1.5 billion people in locations with at least 1 million people, $35 \%$ live in tropical urban agglomerations ${ }^{2}$, such as Mexico City, Mumbai, Kolkata, Rio de Janeiro, Manila, Lagos, Guangzhou, Kinshasa, Shenzhen, Jakarta and Lima (Norris, 2014). The challenge is to manage the rapid expansion of cities, especially in the low- and lower-middleincome nations (Glaeser, 2014).

\section{How Do Cities Grow?}

A city is a living entity. Pundits who believe that cities are simply large towns are followers of a "pre-formation" theory of city growth, an enlargement of what is essentially already there. Jacobs $(1969,1984)$ argues against the pre-formation theory of city growth and promotes the "epigenesis" theory, which maintains that a city grows by a process of gradual diversification of and differentiation in its economy. Jacobs views urbanisation economies, arising from the diversity of industries in a city, as the main factor conducive to this growth. Furthermore, cities are not simply material spaces - as living entities they are also spaces of the imagination.

Large cities and urban agglomerations in the tropics attract many people wanting to work and live in them because of better job opportunities and higher living standards. How these cities are envisioned has effects. Chakravorty (2003) suggests that urbanisation economies arise from diverse labour pools, access to specialised services, inter-industry information transfer, social infrastructure and urban amenities. The great cities of Manchester and Glasgow in the United Kingdom originated from successful urban agglomerations. Jacob's conclusion is reiterated by Lucas (1988) in the context of new growth economics, in which cities supply the human capital necessary to support economic activity, thus forming a virtuous cycle.

\footnotetext{
${ }^{2}$ According to Norris (2014), the United Nations defines urban agglomeration as "large cities that do not necessarily conform to city boundaries". A single large urban agglomeration may comprise several cities or towns and their suburban fringes.
} 
As with many post-World War II decolonised nations, Singapore was lacking in every aspect of socio-economic development during the period of its independence in 1965. Yet today, even with 7,829 people per square kilometre of land area, ${ }^{3}$ Singapore is a highly successful tropical urban city. The nation's public housing policy has provided almost every eligible person in the country with a roof over their heads. The intention of this paper is to review artefacts and historical data of the post-war period in order to analyse the stance adopted by the government and society regarding the development of public housing in Singapore. It is noted the Singapore imaginary is one of development.

Methodologically, this paper employs a case study approach in understanding the life of public housing in Singapore. Case histories are important as they contribute to a better understanding of 'possible causes, determinants, pathways, processes and experience' that may lead to a particular outcome (Hakim, 2000: 64). One singular case is adequate if the case is 'revelatory' (Yin, 1994: 41). The paper uses Scott's (1990) criteria of authenticity, creditability, representativeness, and meaning to assess published sources of evidence. Multiple sources of data are used as this is less prone to 'quirks derived from a single source' (Yin, 2003). Having data from multiple sources leads to data triangulation (Yin, 2003; Stake, 2000), which makes the case method attractive.

Singapore's public housing, from a developmental point of view, is a major success. This article first discusses the legacy from the pre-nation building period to the initial remit in constructing public housing for rental purposes. Next, it attempts to shed light on the experimental ideas for social housing, the forceful acquisition of land, and resultant destruction of communities by the young nation. The third section looks at how the HDB represents and incorporates sustainable features and tropical design into existing and newer townships, and continues to rejuvenate its older estates. Finally, the article revisits and discusses some successes and failures in the public housing scheme. The last section concludes.

\section{Colonial Improvement Scheme}

Singapore had been a British colony and one of three Straits Settlements controlled directly from London. Trade was the impetus for the city growth along the Singapore River and surrounding enclaves such as Chinatown. In 1918, a commission was tasked to review the living conditions in central Singapore (Legislative Council, 1918). As a result, the Singapore Improvement Trust (SIT) was conceived in 1924 and constituted in 1927 after the Singapore Improvement Ordinance was passed. The objective was to "provide for the improvement of the town and island and Singapore" (Yeh, 1975, p. 3), specifically the central district e.g. Chinatown

\footnotetext{
${ }^{3}$ Retrieved from World Bank (http://data.worldbank.org/indicator/EN.POP.DNST).
} 
where housing conditions were dilapidated and overcrowded. The initial purpose of SIT was not to build housing for the general populace but only to provide for the homeless through improvement schemes and to resolve overcrowding issues. Only in 1932 was SIT given powers to undertake new building projects to accommodate the rapidly growing population. Its building efforts, however, were far from adequate, as the housing situation worsened from Singapore's rapidly growing population, especially after World War II (Yeh, 1975). One of SIT's earliest projects was the Tiong Bahru housing estate in Singapore, which is regarded as the first public housing estate in the country (See Figure 1). Tiong Bahru was considered the suburban area of Singapore, three kilometres from the estuary of Singapore River, but not exactly a farmland or village. The building of social infrastructure and urban amenities in Tiong Bahru was possibly the earliest economy derived from urbanisation.

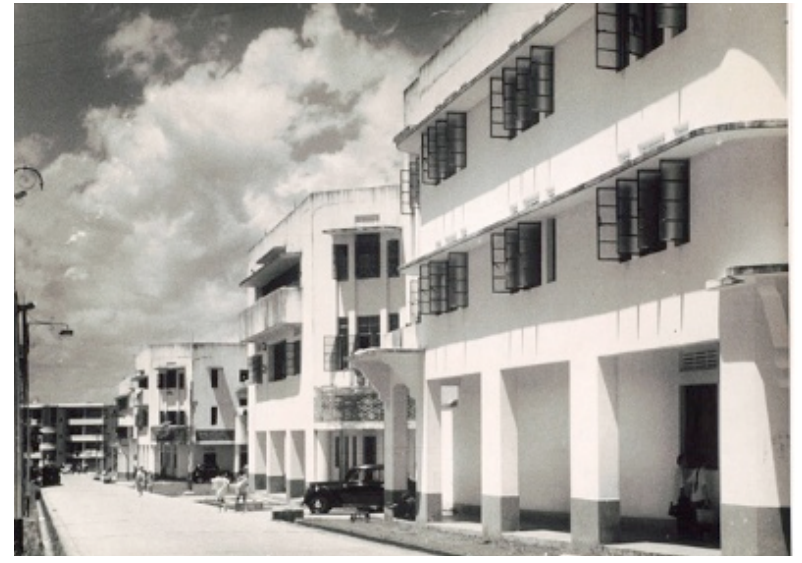

Figure 1. SIT flat in Tiong Bahru, c. 1953 Image from National Museum of Singapore

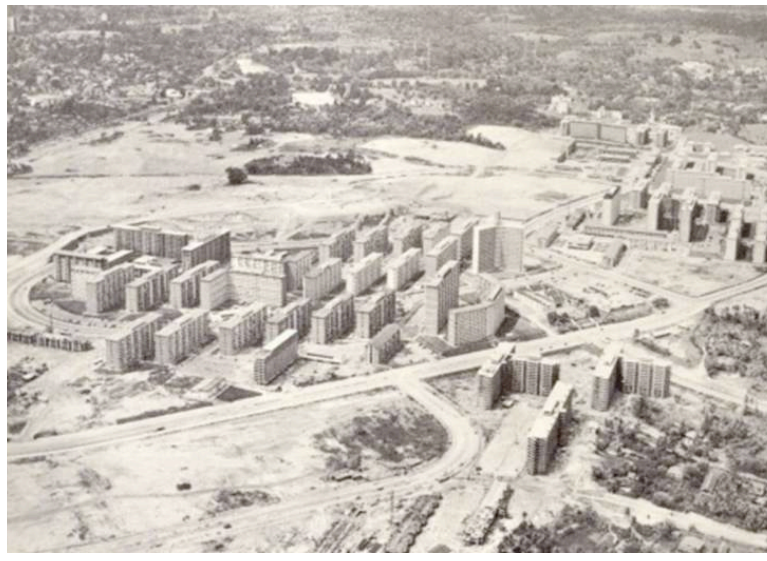

Figure 2. Construction of Toa Payoh, c. 1965. Image from Straits Times

The period of colonisation and the SIT however did not adequately address nor resolve the housing issues. By the time Singapore attained self-government in 1959, the housing shortage had reached alarming proportions. Concomitant problems such as overcrowding and squatter colonies grew. According to a 50-year review by the Ministry of Health in Singapore, squalid living conditions, coupled with an inadequate provision of primary health care, triggered frequent epidemics (Tong \& Narayan, 2015). In the 1960s, it was estimated that as many as 1.3 million people (of a population of 1.9 million) lived in squatter settlements near the urban core (Centre for Liveable Cities, 2013). To address the issue of providing adequate living conditions for the population, the Housing and Development Board (HDB) was established in 1960 by the new Singapore government to replace SIT as the national housing authority. 


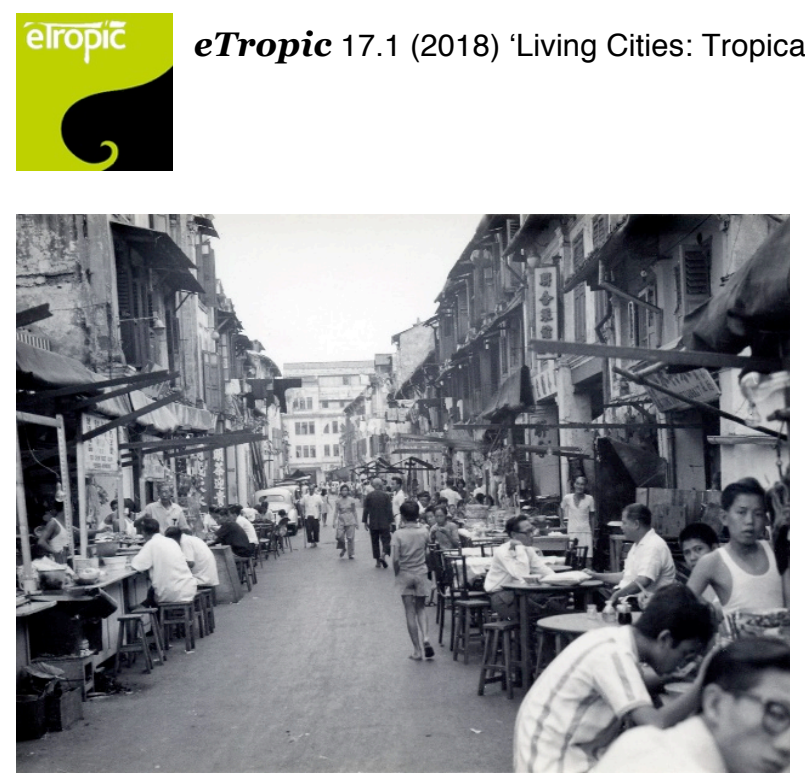

Figure 3. Chinatown, c. 1966 Image from David Ayres via Flickr

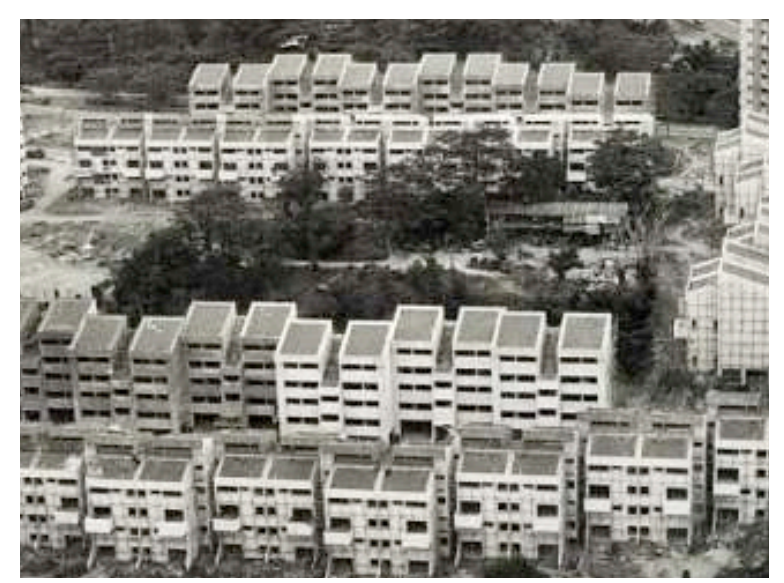

Figure 4. HUDC flat in Gilman Heights, c 1984 Image from The Straits Times

\section{Many Ideas, One Winner}

The HDB had been given the initial remit to construct public housing (also known as apartments or flats) for rental purposes. Toa Payoh New Town is the first housing estate built by the newly instituted HDB (Figure 2), with the experiences and knowledge accumulated from the SIT. The new focus of the HDB, however, was on the rapid mass production of small, affordable, standardised housing for low-income groups. Aspects of size and individuality were sacrificed in those smaller standardised units, but the HDB's most urgent task was to cater to a growing population. Data extracted from The Straits Times (1964) shows Singapore's rate of population increase at that time was approximately $4.3 \%$, or between 50,000 and 60,000 citizens added to the population each year, hence justifying this urgency.

Soon, in 1964, the HDB began selling flats under a home ownership scheme. In 1968, the government implemented another scheme that allowed Central Provident Fund members to use their social security funds to finance their purchases of HDB flats instead of relying solely on their meagre take-home pay. The CPF is a mandatory social security savings scheme funded by contributions from both employers and employees. The ability to make use of the CPF to purchase HDB flats, and integrate the CPF and HDB into Singapore's financial system (Lee, 2009; Lim 2001) have been recognised and widely reported.

As a young nation, there were many ideas of how to create a livable city, with numerous experiments. A limited number of public flats for low-income workers were also constructed between 1968 and 1982 by the Jurong Town Corporation, another statutory board, in Jurong and Sembawang estates. The Housing and Urban Development Company (HUDC) also provided housing unique to Singapore (Figure 4). The government set up this company in 1974 to cater to the middle-income groups who could afford something better than the typical public 
housing, or HDB flats, yet still found private housing unaffordable (Tan \& Phang, 1991). During the 1960s and 1970s, extensive urban renewal projects were undertaken in Singapore to address the problems of a young nation. The housing shortage had forced the government to develop several schemes to create townships in different districts. The critical tasks for the government then were to clear out the slums, provide public housing, and encourage economic growth by creating more space for industries by reclaiming agricultural land.

\section{Land Acquisition for Social Justice or Urban Planning?}

The 1960 Housing and Development Act legislatively gave the HDB absolute control over the use of private property as well as the restriction of private property rights through the use of the 1967 Land Acquisition Act. Armed with the ability to acquire land for the building of public housing projects, the HDB became the most powerful property developer in Singapore (Yuen, 2002). Together, both acts mandated that whenever any particular land was of public benefit, utility or interest, the President could, by conclusive notification published in the Gazette, declare that land was required for the purpose specified (Wong \& Yeh, 1985; Yeh, 1975). As a result, a number of farmlands and villages in Singapore were acquired, uprooting those kampong (village) and rural dwellers into more urban spaces. Within a developmental imaginary, these acts were seen as important vehicles that paved the way for urban development in Singapore.

Between 1960 and 1965, the HDB built 53,777 housing units mainly for rental (Teo \& Huang, 1996). By 1969, the HDB had constructed its first 100,000 flats. Housing designs were kept simple and functional, comprising slab blocks to create one- to three-room partitions and essential amenities such as running water and electricity. The Urban Renewal Unit in 1964 (renamed the Urban Renewal Department, or URD, in 1966) undertook a comprehensive overview of urban renewal and redevelopment of the Central Area. The URD set the foundation for good urban planning and design. Ancillary services such as wet markets, shops, recreation facilities (e.g. cinemas, playgrounds), bus interchanges (bus ports) and schools were embedded in every housing estate or township. Combining efforts from URD, the Planning Department, the HDB, the former Public Works Department, and the United Nations, Singapore's first Concept Plan was created in 1971. On 1 April 1974, the URD was converted into the Urban Redevelopment Authority, a statutory board under the Ministry of National Development. 


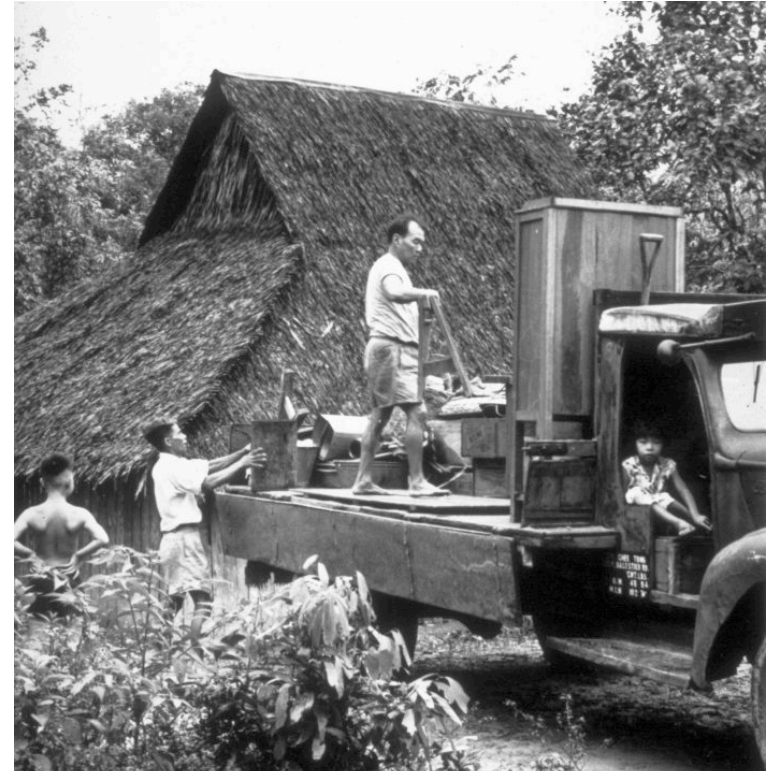

Figure 5. Kampong residents moving to high-rise living in HDB

Image from National Library Board of Singapore

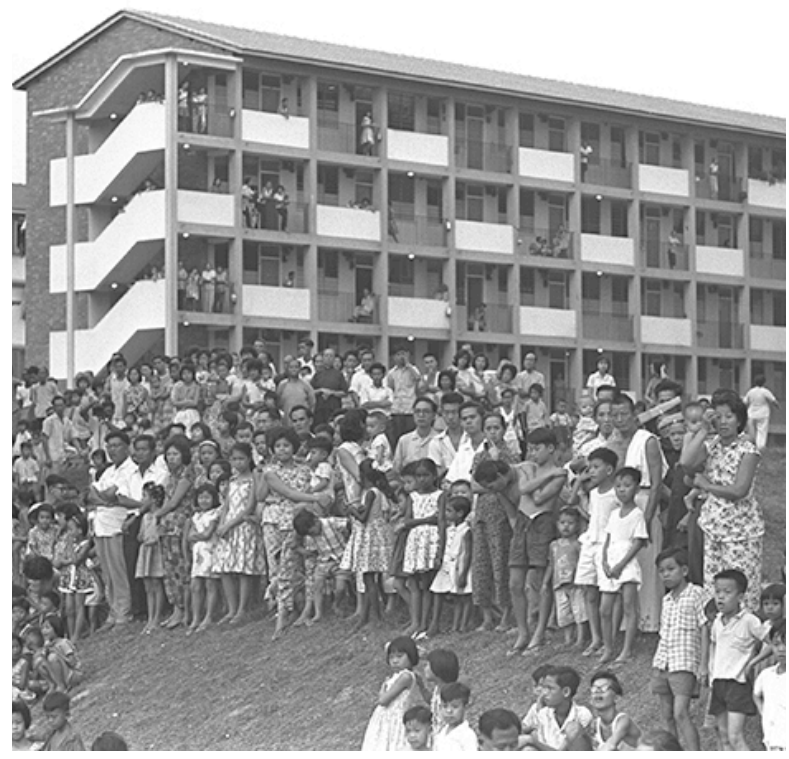

Figure 6. New flat dwellers awaiting the arrival of the Prime Minister in the new housing estate, Havelock,1963 Image from National Library Board of Singapore

Some argued that the resettlement projects (under the 1967 Land Acquisition Act) were implemented in the name of social justice (Wong \& Yeh, 1985). The resettlement of downtown tenement and rural village dwellers to new high-rise flats with proper sanitation services would be a welcomed improvement to the living conditions of the population (Figure 5 and Figure 6). However, leading sociologists, such as Stella Quah (1983), argued that this was forceful acquisition of land below market value and that the resulting destruction of close-knit and established communities went against the principles of social justice.

Communities that had lived in kampong's and rural areas certainly took some time to adapt to the lack of open space and needed to change their lifestyles and social habits as they moved to the HDB flats (see Figures 5 and 6). Large extended families, common to kampong dwellings, were forced to break up into several smaller households and had to live apart. Instead of having dirt pathways that connected kampong houses, new flat dwellers had to get used to a narrow concrete corridors linking different apartments and households. Instead of large wooden "attap" (thatch roofed) houses, new flat dwellers had to get used to smaller concrete units with a single bedroom, hall and kitchen. Social activities such as ancestor worship (including burning of joss papers) were forbidden in and near the flats because it was deemed a fire hazard. Convenient gas stove cooking replaced the old fragrant charcoal-fired cooking. The previous kampong dwellers, though they now had modern sanitation, gas and electricity, had to learn how to adapt 
to these modern ways of living. New flat dwellers joked amongst themselves that they were living in "concrete pigeon holes".

As the country's public housing crisis was surmounted, the HDB began moving away from the "Fordist mass production system" (Wong \& Yap, 2003, p. 368) toward building homes with higher-quality finishes and enhanced fittings. The HDB also began working earnestly with other government agencies and private sector organisations to include sports facilities (e.g. football stadiums, swimming pools), rail networks, green spaces and landscaped parks, and shopping malls in the townships. The newer townships were certainly becoming more attractive and selfsufficient at this time, with access to better amenities and transportation.

In 1982, the HDB also took over the management of the Jurong Town Corporation and HUDC flats and became the sole provider of public housing in Singapore (Khalik, 1982; Tan \& Phang, 1991). As of March 2008, 82\% of the resident population live in HDB flats (HDB, 2008, p. 58).

\section{The HDB in the $21^{\text {st }}$ Century}

The HDB had built economic and functional flats in its first decade of operation in the 1960s. Larger three-bedroom apartments (also known as five-room flats) were introduced in the 1970s, followed by executive apartments and maisonettes in the 1980s. This was in response to the demand for larger flats (Wong \& Yeh, 1985); city imaginaries and urbanisation demanded larger accommodation and better standards from the HDB. In keeping with Singapore's developed nation status, the 1990s ushered in HDB-designed homes to meet the aspirations of a more affluent and better-educated population. HDB flats were built higher with eye-catching architecture incorporating more natural lighting and space to congregate. Shelters and integrated structures linked community, commercial and sporting facilities as a hub for residents. By 1997, the HDB unveiled a special range of flats known as studio apartments for Singapore's ageing population. These homes are smaller and partially furnished with elderlyfriendly features such as emergency pull cords linked to an alert system for summoning help (Yap, 2007).

As it moved into the $21^{\text {st }}$ century, the HDB began piloting initiatives such as the Smart HDB Town Framework, which represented the new city living standards in leveraging information and communication technology. New HDB townships are designed using computer simulation and data analytics, with complex systems modelling tools used to integrate new technologies such as solar energy, LED lighting, rainwater harvesting, pneumatic waste collection and vertical greenery.

Smart technology is adopted to optimise energy usage in homes, to develop alert systems to ensure the safety of relatives at home, and to install sensor-activated lighting systems in 
common areas. In addition, the HDB Greenprint project aims to introduce energy-efficient water and waste management features into HDB housing estates. HDB towns of the future will have enhanced greenery through the provision of green roofs and vertical greenery in an effort to decrease the surface temperature of residential buildings. An "eco-living" concept is also being promoted by setting aside more cycling tracks and installing bicycle parking racks to promote green commuting and encourage residents to interact in green spaces. Better lifestyle facilities are being introduced through such smart and eco-town programs in which natural features such as waterways and greeneries are integrated in the design of new housing estates to create luxurious waterfront and resort-like living environments.

Adding to the variety of public housing and city imaginaries is the Design, Build and Sell Scheme (DBSS) introduced in 2005. Under DBSS, designated sites are sold to private developers, which are then responsible for designing, building and selling the flats (Business Times, 2007). Figure 7 shows the HDB plans for the $21^{\text {st }}$ century integrating greener living environment, enhanced connectivity and distinctive housing districts.

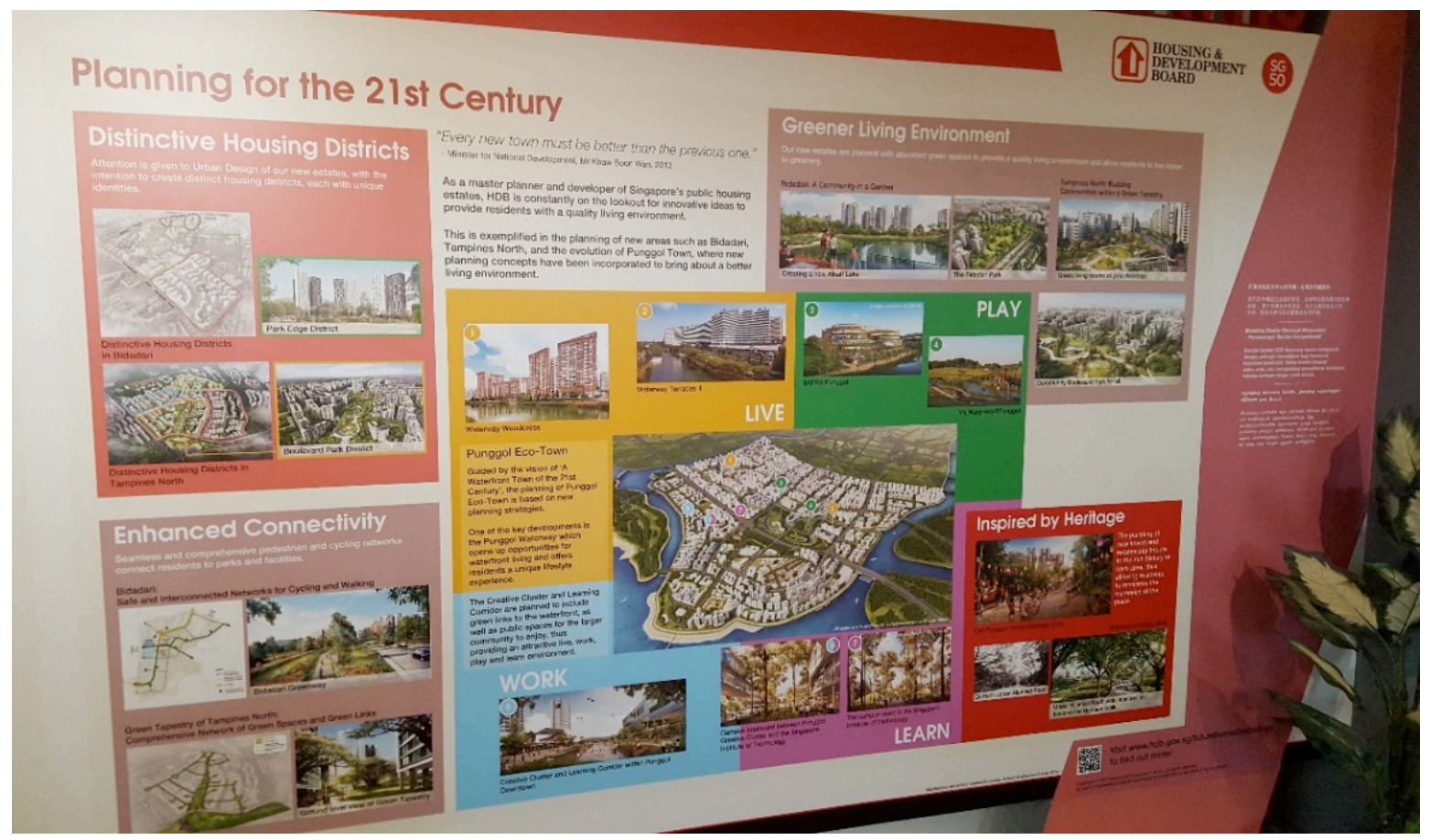

Figure 7. HDB planning billboard

Image by Suhaimy Hassan (taken at HDB Hub)

Older HDB housing estates have, in many cases, also undergone rejuvenation, especially those in neighbourhoods built between the 1960s and 1980s. The HDB Estate Renewal Strategy 
involves retrofitting flats, modernising town centres, installing lifts that stop at all floors, upgrading communal facilities, and enhancing road and transportation networks in the older housing estates. Through such upgrading programs, older residential neighbourhoods have been transformed with modern facilities and amenities akin to those being added to new housing estates.

\section{Urban Rejuvenation: Friend or Foe?}

Many older housing estates are being replaced by new developments as a result of Singapore's rapid urbanisation. Urbanisation and city living, in the case of Singapore, has always been imagined in the context of modernisation. Thus, although the Cantonment Road housing estate had historic significance as the site of the first two 10-storey HDB blocks in the Tanjong Pagar district, it was demolished to make way for the new. Figure 8 shows Member of the Parliament and former Prime Minister Lee Kuan Yew inspecting the model of "Chap Lau Chu" or 10-storey flats in his constituency of Tanjong Pagar, with Lim Kim San, who was the chairman of the HDB at the time (from 1960 to 1963). Figure 9 shows the two 10-storey flats in the 1980s, residing on the city outskirts, next to the Central Business District and Financial Centre of Singapore (see top right of Figure 9). These two buildings were at the beginning of this century demolished to make way for the Pinnacle@Duxton development.

Chap Lau Chu, in its modular form, holds many memories for members of the baby boomer generation as it was their first childhood home. Inside, long corridors connected some 10 or more households on the same level. Common stairwells linked one floor to neighbours above and below. Children, who used to play in open fields in kampongs, now ran along common corridors with their neighbourly counterparts. Communal etiquette was certainly necessary to manage the noise level (e.g. shouting, family quarrels, even renovation work) and maintain good relationships with neighbours on both sides, but also on the floors above and below. Many of these Chap Lau Chus, built in new towns such as Toa Payoh (Figure 2) and Havelock (Figure 6 ), have now almost completely disappeared; their demolition is a reminder of the heady pace of Singapore's progress. Chap Lau Chus were home to many people, including the elderly and those living in rental flats. Now, however, they are becoming a rare sight in modern Singapore, almost extinct as a result of the urban renewal programme. 


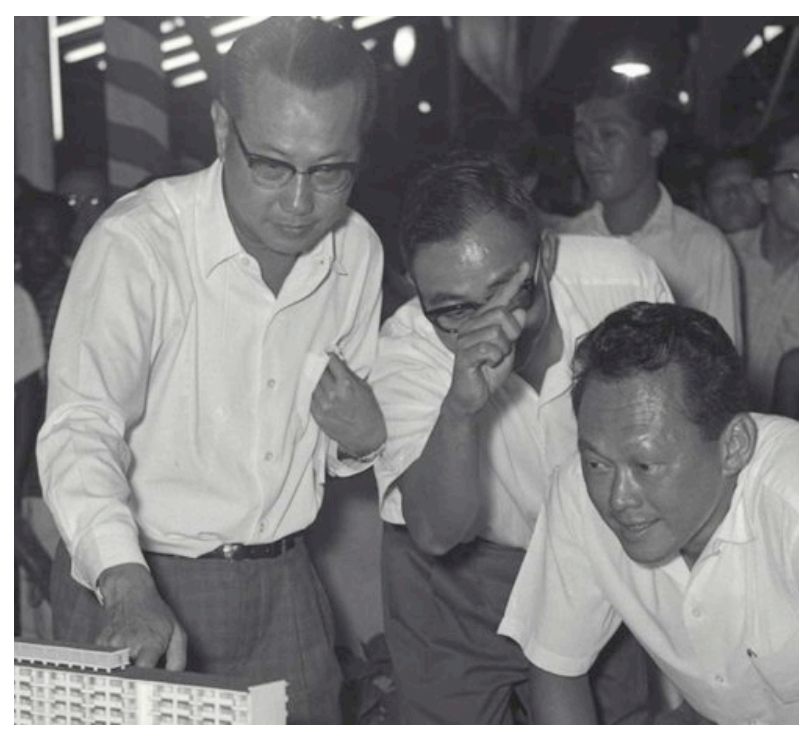

Figure 8. Lee Kuan Yew (right) and Lim Kim San (left) looking at the model of Cantonment Road Estate, 1963 Image from Asia One

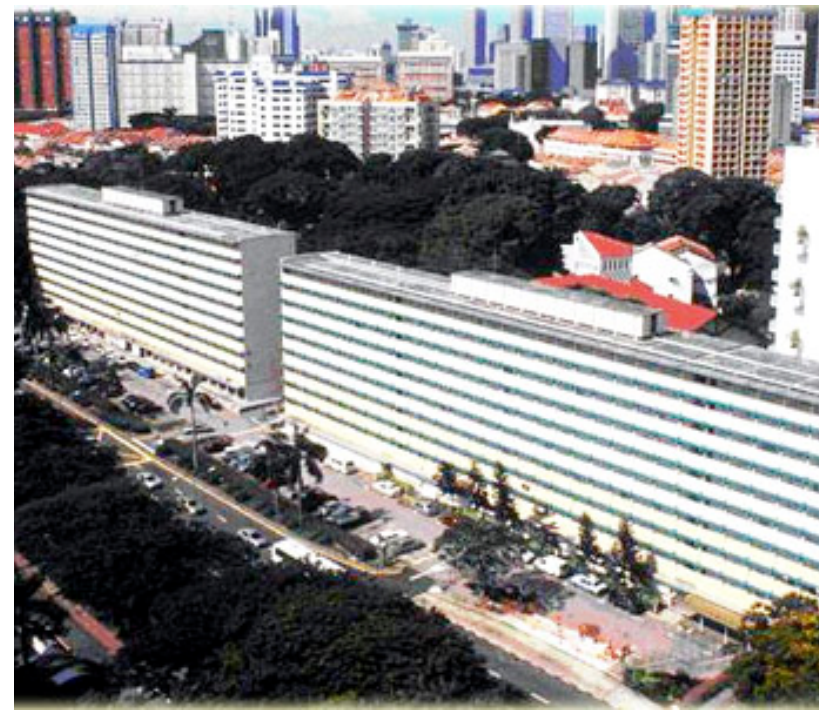

Figure 9. Chap Lau Chu: 10-storey flats in Cantonment Road housing estate. Image from The Straits Times

In 2001, Lee Kuan Yew, as Member of the Parliament for Tanjong Pagar from 1955 till his death in 2015, initiated the redevelopment of the Cantonment Road housing estate. Some critics argued that Lee wanted to showcase $21^{\text {st }}$ century Singapore "in the founding prime minister's Tanjong Pagar constituency, no less" (Han, 2015). In the place of the Chap Lau Chus was one of the grandest public housing developments ever built, the Pinnacle@Duxton (see Figure 10). On the 26th and 50th floors the project features two of the world's longest sky gardens, of 500 metres each, connecting seven tower blocks. As the city fringe expanded with urban redevelopment, many of the original residents, now in their seventies and eighties, had to relocate to nearby flats, thus moving these residents away from their comfort zones, social circles and communities.

As the city centre and economic activities continue to diversify in Tanjong Pagar, older buildings have made way for office blocks and city accommodation. The Pinnacle@Duxton project holds the record for the highest average price of new flats purchased directly from the HDB, as well as the most expensive unit sold, at $\$ \$ 646,000 .{ }^{4}$ The Pinnacle@Duxton was awarded "Best Tall Buildings" in 2010 by the international Council on Tall Buildings and Urban Habitat, which recognises noteworthy projects across four geographic regions (Americas, Asia \& Australasia,

\footnotetext{
${ }^{4}$ The flats in the Cantonment Road area are among some of the most expensive new units - with a fourroom S1-type priced between $\$ 457,000$ and $\$ 555,000$, while the larger $S 2$ units cost between $\$ 545,000$ and \$646,000 (http://www.lushhomemedia.com/manage_posts/2008/09/29/pinnacle-flats-on-offer-2/).
} 
Europe, and Middle East \& Africa). Each apartment at the Pinnacle@Duxton now fetches in excess of $\$ \$ 1,000,000$ on the secondary property market. ${ }^{5}$

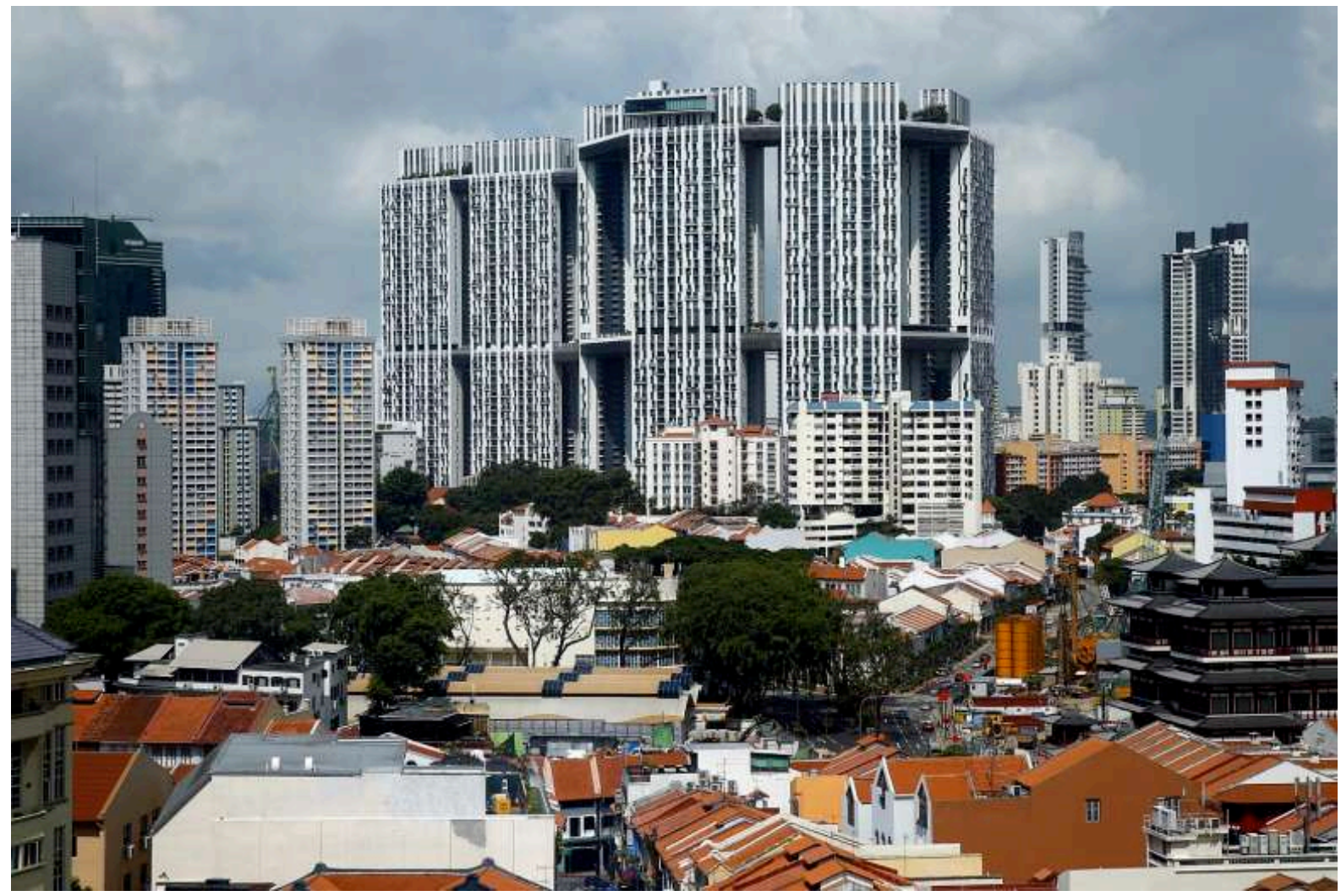

Figure 10. Cantonment Road housing estate replaced by Pinnacle@Duxton. Image from The Straits Times

Although the Pinnacle@Duxton is classified as public housing of the DBSS under the HDB, the location of this attractive development in a central district of Singapore made this new development most desirable for the upwardly mobile young workers in the city. The Pinnacle@Duxton also plays host to young expatriates who work in the Central Business District who need less expensive rental accommodation. Older residents of the former Cantonment Road housing estate have been displaced by these upwardly mobile young people

\footnotetext{
${ }^{5}$ See https://www.propertyguru.com.sg/property-management-news/2015/01/78843/8-things-you-didntknow-about-pinnacleduxton.
} 
who prefer city dwellings. While half a century ago, the original residents had to get used to living in Chap Lau Chus, they have now been pushed towards the outer fringe of city living.

\section{Successes and Failures of Singapore's Public Housing Scheme}

Singapore's public housing policy is a good example of social and racial cohesion in multi-ethnic and multi-religious Singapore. Public housing in Singapore has been treated as one of the most important aspects binding social and economic development, with important implications for political stability (Chua, 1991). As a multi-ethnic society consisting of three major ethnic groups, Chinese: 74.3\%; Malay: 13.4\%; Indian: 9\% and Others: 3.2\% (Department of Statistics, 2017), it was noticeable that in the early years of independence various groups were living within distinct ethnic enclaves. For example, in the Bedok and Tampines housing estates, Malay households made up more than $30 \%$ of these estates' population. In Hougang housing estate, $90 \%$ of the households were Chinese.

In a bid to address the issue of communal clustering and ethnic enclaves, the government introduced the Ethnic Integration Policy ${ }^{6}$ (EIP) in 1989 to maintain the ethnic balance of residents who are allowed to own their HDB lease and reside in an HDB neighbourhood. This policy dictated that every HDB housing estate must have a stipulated mix of Singapore's major ethnic groups. For the sale and resale of HDB flats, the permissible proportion of flats in each neighbourhood for Malays was $22 \%$ while the permissible proportion of flats in each block was $25 \%$. The permissible proportions for those of Chinese origin was $84 \%$ and $87 \%$, respectively, and for Indians and other minority groups, the figures were $10 \%$ and $13 \%$, respectively (Parliamentary Debates Singapore Official Report, 1989). Owners were free to sell their HDB flat lease to a buyer of any race as long as the racial limits were maintained (Wee, 1989). These limits, set on the total percentage of a neighbourhood and a block of flats, are updated on the 1st of every month to reflect the composition. This means HDB leaseholders are free to buy and sell flats if they are of the same ethnicity. But should HDB leaseholders want to buy or sell from someone of a different ethnicity, they will only be able to do this if the sale won't result in a percentage change of that ethnicity in a rolling month.

\footnotetext{
${ }^{6}$ The Ethnic Integration Policy was implemented on 1 March 1989 to promote racial integration and harmony in HDB estates http://eresources.nlb.gov.sg/history/events/d8fea656-d86e-4658-9509$974225951607 \# 3$.
} 
This coordination restricted the freedom of sales of HDB leases; however, with such coordination aided by the government, Singapore has managed to solve its housing problems and racial cohesion issues within a few decades. All people were resettled by 1985 and there is no evidence of any squatter settlement in Singapore today (Liu \& Chua, 2016). The housing policy has brought other benefits to low-income groups. Among these are the improvement of living conditions, including sanitation, public utilities, and more living space. Indeed, by 1975 approximately $75 \%$ of the slums had been cleared. The average living space in these slums was less than 3.3 square metres per person, while, as of three decades ago, the average size of a flat is almost 74 square metres for a family of five, or 14.8 square metres per person (Quah, 1983). Today, more than $86 \%$ of the population lives in HDB flats, and the home ownership rate of HDB residents is $93 \%$ (Phang, 2018).

In the last 10 years, the HDB has won several notable international awards ${ }^{7}$ for its success in providing homes for the masses. In a 2014 survey conducted by the Institute of Public Studies to assess the perception of Singapore's history, the formation of the HDB was ranked as one of the 10 events most important to Singaporeans. ${ }^{8}$ Singapore's massive public housing programme has been hailed a phenomenal successful (Tremewan, 2006) and heralded as the party-state's greatest achievement. According to Pugh (1989, p. 873), public housing in Singapore is 'a symbol of pride, of nationhood, of the political achievement... and of government benevolence towards the public interest'.

\footnotetext{
${ }^{7}$ Notable recent international awards include

i. "Best Tall Buildings" award by the Council on Tall Buildings and Urban Habitat (CTBUH) in 2010 for the Pinnacle@Duxton.

ii. UN-Habitat Scroll of Honour "for providing one of Asia's and the world's greenest, cleanest and most socially conscious housing programmes" in 2010.

iii. United Nations Public Service Award (UNSPA) for its Home Ownership Programme in June 2008. "The UNPSA is one of the most prestigious international awards for excellence in public service, and the HDB is the only winner in the Asian region among 12 worldwide" (see www.hdb.gov.sg/cs/infoweb/about-us/achievements-and-accolades/achievements/pastachievements).

${ }^{8}$ In this study by the Singapore's Institute for Policy Studies, "respondents were taken through a list of 50 historical events - from the founding of modern Singapore in 1819 to the last general election in 2011 and asked if they were aware of the event" (see http://lkyspp.nus.edu.sg/ips/news/ips-study-onperceptions-of-singapores-history and http://lkyspp.nus.edu.sg/ips/wpcontent/uploads/sites/2/2013/04/CNA_Pioneers-lauded-ahead-of-HDBs-55th-birthday_310115.pdf).
} 


\section{Conclusion}

Global cities and urban tropical agglomerations attract migrants from around the world because of greater job opportunities and good living standards. Urban agglomerations will continue to engulf surrounding areas, as a city grows through a process of diversification and differentiation. At 7,829 people per square kilometer of land area $^{2}$ Singapore is one of the most densely populated city-states in Asia. Singapore boasts a diverse labour pool, access to specialised services, social infrastructure, urban amenities, and a growing creative arts scene, attractive to both locals and foreign companies and expatriates.

Singapore did not always have this image as a vital city of the tropics, and in its early years of independence had to overcome basic needs to create a livable city. Singapore's HDB illustrates how city administrators can adopt a holistic government approach to providing home ownership to solve the housing crisis and allow the populace to own homes. HDB homes represented an asset during nation building when most people had lived in large extended family homes in the 1960s, resulting in ghettos in some cases. The HDB had its predecessors in the form of the SIT prior the 1960, which laid a foundation in the building of social housing. The ability to make use of the CPF to purchase HDB flats, and integrate the CPF and HDB into Singapore's financial system is another key success factor. The Singaporean government had earlier encouraged setting up nuclear families and used home ownership as a means to pursue its nation-building objectives (Tan \& Naidu, 2014). The same government, five decades later, now promotes living close to parents and even having a granny unit within the HDB apartment. Thus, the HDB has furthered its ambition by staying agile of evolving societal and government needs.

For a successful public housing programme to take shape, various branches of a public service must work together to ensure a fruitful outcome. In the case of Singapore, the HDB does the planning and builds the homes. However, in providing other physical amenities, such as roads, train networks, schools, parks, neighbourhood police posts and community centres, a holistic approach involving different government agencies is needed. The HDB has worked with its counterparts from other agencies to build the relevant public infrastructure and to deliver an effective public service.

Other than planning and building award-winning townships that incorporate sustainable features such as energy-efficient water and waste management, the HDB has more recently incorporated tropical design features like green roofs to decrease the surface temperature of existing residential buildings. At the same time, the HDB has consistently rejuvenated its older housing estates through the retrofitting of flats and installing lifts that stop at all floors to support the aging population. Smart and eco-town programs feature waterways and greeneries in the 
tropical design of newer housing estates to support better lifestyle and community activities. Singapore's public housing estates seem to operate as a close-knit community. Evidence of this is that housing estates are no longer crime infested nor racially divided urban ghettos but appealing apartment blocks and lifestyle resorts.

City imaginaries are spaces of representation. How Singapore and the HDB are envisioned has effects. The imaginary about cities is itself in part constituted by representations and practices. Ideas about cities are not simply formed at a conscious level; they are also a product of unconscious desires and imaginaries. In the case of Singapore, this is very much an image of development and modernity: that the old replaces the new. Continuous improvement in Singapore's urban planning has not only provided better access to jobs as foreign companies are attracted to the city-state, but also improved the property prices of HDB homes, which has helped enhance the social mobility of its residents living in this tiny island nation. However, it is also noted that the sustainability of the Singapore development ideal has come under greater focus and questions of green environments and cultural heritage are now surfacing. This is the new emerging imaginary that this living city must engage itself with as it moves into the future. 


\section{References}

Business Times (2007, May 24). Milestones. Retrieved from http://eresources.nlb.gov.sg/newspapers/Digitised/Article/biztimes20070524-1.2.47.53.

Centre for Liveable Cities (2013). Singapore's public housing story. Retrieved from http://www.clc.gov.sg/documents/Lectures/2013/DrLiureport.pdf.

Chakravorty, S. (2003). Capital source and the location of industrial investment: A tale of divergence from post-reform India. Journal of International Development, 15, 365-383.

Chua, B. H. (1991). Not depoliticised but ideologically successful: The public housing programme in Singapore. International Journal of Urban and Regional Research, 15(1), 24-41.

Department of Statistics. (2017). Population Trends. Singapore: Department of Statistics. Ministry of Trade and Industry, Republic of Singapore.

Glaeser, E. L. (2014). A world of cities: the causes and consequences of urbanization in poorer countries. Journal of the European Economic Association, 12(5), 1154-1199.

Han. F. K. (2015, January 11). 50 and celebrating the spirit of questioning. The Straits Times. Retrieved from http://www.straitstimes.com/opinion/50-and-celebrating-the-spirit-ofquestioning.

Hakim, C. (2000). Research Design: Successful Design for Social and Economic Research. Routledge.

Harding, S., Bird, G., Losos, E., Aderolili, R., \& Hotez, P. (2016). International Day of the Tropics: Towards a better global future. eTropic, 15 (2), 5-12.

Harding, S., Trewin, D., Penny, A., Ziembicki, M., Dale, A., Ustan, T.S., \& Jamaludin, S.R. (2017). State of the Tropics 2017 Report: Sustainable infrastructure in the tropics. Townsville, Australia: James Cook University.

HDB. (2008). HDB annual report 2007/2008. Singapore: Housing and Development Board. Jacobs, J. (1969). The economy of cities. London: Penguin Book.

Jacobs, J. (1984). Cities and the wealth of nations: Principle of economic life. New York: Vintage.

Khalik, S. (1982, March 27). Middle income housing now under HDB. The Business Times. Retrieved from http://eresources.nlb.gov.sg/newspapers/Digitised/Article/biztimes19820327-1.2.9.

Legislative Council. (1918, October 15). The Straits Times. Retrieved from http://eresources.nlb.gov.sg/newspapers/Digitised/Article/straitstimes 19181015-1.2.53.

Lee, J. (2009). Developmentalism, social welfare and state capacity in East Asia: integrating housing and social security in Singapore. Journal of Asian Public Policy, 2(2), 157-170. 
Liu, T. K., \& Chua, B. H. (2016). Clarity equals courage: A comprehensive housing policy for Singapore. In A chance of a lifetime: Lee Kuan Yew and the physical transformation of Singapore. Singapore: Centre for Liveable Cities and Lee Kuan Yew for Innovative Cities.

Lim, K. L. (2001). Implications of Singapore's CPF Scheme on Consumption Choices and Retirement Incomes. Pacific Economic Review, 6(3), 361-382.

Lucas, R. (1988). On the mechanics of economic development. Journal of Monetary Economics, $22(1), 3-42$.

Marcotullio, P. J. (2001). Asian urban sustainability in the era of globalization. Habitat International, 25(4), 577-598.

Norris, F. (2014, July 11). For biggest cities of 2030 , look toward the tropics. The New York Times. Retrieved from www.nytimes.com/2014/07/12/business/for-biggest-cities-of2030-look-toward-the-tropics.html? $r=0$.

Phang, S.Y. (2018), Policy Innovations for Affordable Housing in Singapore: From Colony to Global City, UK: Palgrave Macmillan.

Parliamentary Debates Singapore Official Report (1989) Vol. 52, No. 9, cols 650-668 (16 February, Minister for National Development S. Dhanabalan).

Pugh, C. (1989). The political economy of public housing. In K.S. Sandhu \& P. Wheatley (Eds.), Management of success: The moulding of modern Singapore (pp. 833-859), Singapore: Institute of Southeast Asian Studies.

Quah, S. R. (1983). Social discipline in Singapore: An alternative for the resolution of social problems. Journal of Southeast Asian Studies, 19(2), 266-289.

Sandhu, S. C., \& Singru, R. N. (2014). Enabling GrEEEn cities: An operational framework for integrated urban development in Southeast Asia. ADB Southeast Asia Working Paper Series No 9. Asian Development Bank.

Scott J (1990), A Matter of Record: Documentary sources in social research. Polity Press: Cambridge.

Stake, R.E. (2000), Case studies, in Denzin, N.K., and Lincoln, Y.S. (eds), Handbook of Qualitative Research, 2nd Ed, SAGE: California, pp. 435-454.

Straits Times (1964, August 31). A flat every 45 minutes. Retrieved from http://eresources.nlb.gov.sg/newspapers/Digitised/Article/straitstimes196408311.2.134.21.

Tan, A. H. H., \& Phang, S. Y. (1991). The Singapore experience in public housing. Singapore: Times Academic Press.

Tan, S. B., \& Naidu, V. L. (2014). Public housing in Singapore: Examining fundamental shifts. Lee Kuan Yew School of Public Policy. Retrieved from http://lkyspp2.nus.edu.sg/wpcontent/uploads/2014/11/Public-Housing-in-Singapore.pdf. 
Teo, P., \& Huang, S. (1996). A sense of place in public housing: A case study of Pasir Ris, Singapore. Habitat International, 2(2), 307-325

Tong, Y. K., \& Narayanan, S. (2015). Caring for our people: 50 years of healthcare in Singapore. Singapore: Ministry of Health.

Tremewan, C. (2006). Welfare and governance: Public housing under Singapore's party-state. In R. Goodman, H. J. Kwon, \& G. White (Eds.), The East Asian welfare model: Welfare orientalism and the state (pp. 77-105). London: Routledge.

Wee, A. (1989, February 17). Racial limits set for HDB estates. The Straits Times. Retrieved from http://eresources.nlb.gov.sg/newspapers/Digitised/Article/straitstimes198902171.2.2.

Wong, A. K., \& Yeh, S. H. K. (Eds.). (1985). Housing a nation: 25 years of public housing in Singapore. Singapore: Maruzen Asia.

Wong, T. C., \& Yap, A. (2003). From universal public housing to meeting the increasing aspiration for private housing in Singapore. Habitat International, 27(3), 361-380.

World Bank. (2015). East Asia's changing urban landscape: Measuring a decade of spatial growth. Washington, DC: World Bank.

Yap, C. B. (2007, April). Homes for a nation - Public housing in Singapore. Ethos, 2. Retrieved from

https://www.cscollege.gov.sg/Knowledge/ethos/lssue\%202\%20Apr\%202007/Pages/Ho mes-for-a-Nation-Public-Housing-in-Singapore.aspx.

Yeh, S. H. K. (1975). Public housing in Singapore: A multi-disciplinary study. Singapore: Singapore University Press.

Yin, R.K. (1994) Case Study Research: Design and Methods, 2nd ed., Sage Publications, Thousand Oaks, CA.

Yin, R.K. (2003), Applications of Case Study Research, 2nd Ed. Sage: Thousand Oaks, CA

Yuen, B. (2002). Singapore. In M. R. Agus, J. Doling, \& D. Lee (Eds.), Housing policy systems in South and East Asia (pp. 38-59). Basingstoke, England: Palgrave MacMillan. 